\title{
Acid Sulfate Soil Induced Acidification of Estuarine Areas Used for the Production of Sydney Rock Oysters, Saccostrea glomerata
}

\author{
Michael C. Dove ${ }^{1^{*}}$, Jesmond Sammut ${ }^{2}$ \\ ${ }^{1}$ Port Stephens Fisheries Centre, NSW Department of Primary Industries, Taylors Beach, Australia \\ ${ }^{2}$ Australian Wetlands and Rivers Centre, School of Biological, Earth \& Environmental Sciences, \\ The University of New South Wales, Sydney, Australia \\ Email: "michael.dove@dpi.nsw.gov.au
}

Received December 10, 2012; revised January 10, 2013; accepted January 18, 2013

\begin{abstract}
This study investigated estuarine acidification, associated with drainage and excavation of acid sulfate soils, in areas used for commercial cultivation of Sydney rock oysters (Saccostrea glomerata). Regular measurements of $\mathrm{pH}$ and electrical conductivity were collected in oyster cultivation areas and acidified reaches of the Hastings River estuary and Port Stephens estuary located on the mid north coast of New South Wales, Australia. Water quality information from acidified floodplain drains was also collected in the Hastings River following heavy rainfall. Both estuaries experienced acidification of tributaries following periods of heavy rainfall. Drain outflow waters were acidic $(\mathrm{pH}<3.5)$; contained elevated concentrations of iron, aluminium, manganese and zinc; and polluted areas used for oyster production. The extent and duration of estuarine acidification events was capable of causing a variety of short- and long-term impacts to oysters as well as other aquatic organisms in affected areas.
\end{abstract}

Keywords: Estuarine Acidification; Acid Sulfate Soil; Sydney Rock Oyster; Saccostrea glomerata; New South Wales

\section{Introduction}

Estuarine acidification caused by outflows from drained landscapes containing acid sulfate soils (ASS) is a recurrent problem in many estuaries in New South Wales (NSW), Australia including those used for Sydney rock oyster (Saccostrea glomerata: SRO) cultivation [1]. Production of SROs has occurred in estuarine areas of eastern Australia for over 130 years and is the largest aquaculture industry in NSW, worth approximately US\$29 million annually [2]. However, annual production has decreased by more than $60 \%$ over the past 30 years. QX (Queensland unknown) disease outbreaks, competition from Pacific oysters (Crassostrea gigas) and declining water quality in estuarine areas used for oyster production have all contributed to reduced production $[3,4]$.

Acid sulfate soils (ASS) contain the mineral iron pyrite $\left(\mathrm{FeS}_{2}\right)$ which is harmless to the environment in the waterlogged environments of undisturbed coastal lowlands [5]. Drainage, disturbance or excavation of ASS exposes iron pyrite to the atmosphere causing it to oxidise and generate sulfuric acid. Sulfuric acid attacks soil minerals, releasing metals contained in the soil including

"Corresponding author. iron, aluminium and manganese [6]. Engineered drainage channels, which are a common feature of eastern Australian estuarine floodplains, provide a route by which ASS oxidation products, originating from groundwater in contact with the soil, can enter estuaries during wet periods [6]. Generally the worst cases of estuarine acidification occur on the east coast of Australia when an extended dry season is followed by heavy rainfall; acid production rates are up to $300 \mathrm{~kg}$ of sulfuric acid per ha per year [6].

Increasing pressure on the environment from expanding coastal populations in eastern Australia is a threat to the oyster industry and other stakeholders. Mapping of ASS has been undertaken in NSW by the Department of Environment and Climate Change and has identified approximately 400,000 hectares of these soils in coastal regions of NSW [7]. Environmental management of coastal floodplains and estuarine ecosystems is shared by local and state government agencies and varies between different catchments. The Sydney rock oyster industry in NSW has been a strong influence in setting environmental goals for water quality management in estuarine systems.

Oyster growers first linked acidic, floodplain outflows 
with poor oyster production in the 1990s and alerted government authorities and scientists to this problem. A field study confirmed this association and found that $S$. glomerata had reduced growth and increased mortalities at oyster leases impacted by estuarine acidification caused by outflows from ASS-affected landscapes [1]. The reasons for reduced growth and survival of oysters in the field were then investigated using laboratory experiments [8]. Weakly acidified water ( $\mathrm{pH}$ 5.5) prevented S. glomerata from feeding at the same rate as oysters in normal $\mathrm{pH}$ water $(\mathrm{pH} 8.5)$. Additionally, acidic treatments $(\mathrm{pH}$ 5.1) that contained elevated concentrations of aluminium or ASS-affected water caused changes in the mantle and gill soft tissues following short term $(6 \mathrm{~h})$ exposure. Degenerative effects were also due to the iron contained in ASS-affected water which accumulates on oysters' soft tissues and is ingested by the oysters. Additionally, very small changes in estuarine water $\mathrm{pH}$ are known to impact fertilisation success and early development of SRO larvae $[9,10]$.

Knowledge of the characteristics of estuarine acidification is important to understand ecological impacts and effects on particular aquatic species $[6,11]$. pH and electrical conductivity (EC) are two important physicochemical water quality parameters for SRO health and are strongly influenced by outflows from ASS. This study examined the changes in $\mathrm{pH}$ and $\mathrm{EC}$ caused by outflows from ASS-affected landscapes on the mid north coast of NSW. Spatial characteristics of drainage waters from extensively drained ASS were investigated in tidal reaches of the Hastings River estuary, whilst temporal changes to $\mathrm{pH}$ and $\mathrm{EC}$ were investigated on an oyster lease in Port Stephens. The consequences of altered water quality conditions induced by ASS outflows for Sydney rock oyster production are discussed.

\section{Study Area}

The study was undertaken on the mid north coast of NSW, Australia and sampling was conducted throughout the tidal areas of the Hastings River (Figure 1) and on an oyster lease in Port Stephens (Figure 2). The Hastings River produces only $4.5 \%$ of the State's Sydney rock oysters for consumption but is the largest supplier of naturally-caught wild oyster spat to other estuaries [2]. Port Stephens is approximately 160 kilometres south of the Hastings River and is the only estuary in NSW where both diploid Pacific oysters, Crassostrea gigas, and $S$. glomerata can lawfully be commercially cultivated. This estuary is the third largest oyster-producing estuary in NSW and sold approximately 0.7 million dozen SROs and 0.2 million dozen Pacific oysters in 2006/2007 [2].

The Hastings River catchment contains approximately 21,000 ha of high risk ASS [7]. Drains have been exca- vated into the ASS to lower watertables to facilitate dryland agriculture. Floodgate structures, constructed in the 1960s and 1970s, are a common feature of floodplain drains that flow into the Hastings River, Limeburners Creek, Fernbank Creek, Maria River, Wilson River, Connection Creek and Pipers Creek (Figure 1) [12] causing the once brackish and tidal reaches upstream of the gates to be fresh-water dominated. Most floodgates have oneway flap gates that release drain waters on the ebb tide but are forced closed by the flood tide [12].

Areas of the Hastings River floodplain that were extensively drained and are associated with ASS include: the lower and upper Maria River; Fernbank/Partridge Creek; and Rawdon Island areas [13]. Most oyster production in the Hastings River estuary occurs in Limeburners Creek, Big Bay and the main channel of the Hastings River (Figure 1). A number of oyster leases were abandoned in the Maria River and main channel of the Hastings River, near Fernbank Creek (Figure 1).

The Port Stephens field site was an oyster lease situated in Fenninghams Island Creek, which flows into Tilligerry Creek, a tributary of Port Stephens (Figure 2). Fenninghams Island Creek receives water from the Anna Bay catchment (Figure 2) which is low lying, flat land that has been partly cleared for pasture. Lowest elevation areas in the catchment are either swamps vegetated by Melaleuca and Casuarina species or salt marsh that are occasionally inundated by high tides.

The site is located $1.5 \mathrm{~km}$ downstream of a floodgate structure (Figure 2) controlling the hydrology of an acidified drain ( $8 \mathrm{~km}$ long) that intersects ASS sediments. There is a network of smaller drains (Figure 2) that connect to the main drain which were designed to lower the water table and remove flood waters but have caused oxidation of the ASS and outflows of acidic waters after heavy rainfall $[14,15]$.

There are approximately 19,000 ha of high risk ASS [7] in the Port Stephens/Myall Lakes catchments and no assessments of impacts to oysters from ASS outflows have occurred in this estuary. In June 2006 there was a significant estuarine acidification event in Fenninghams Island Creek caused by outflows from the Anna Bay drain. In February 2008 after heavy rainfall, a plume of low $\mathrm{pH}$ water contaminated with iron oxyhydroxide flocs smothered oyster leases in Fenninghams Island Creek. Originally, there were seven oyster leases in Fenninghams Island Creek used for cultivating both S. glomerata and C. gigas, three of these were still in use in 2006 and four were former lease sites [16]. In April, 2007, Fenninghams Island Creek and Wallis Creek were designated as a Sanctuary Zone of the Port Stephens-Great Lakes Marine Park to protect the habitats, animals and plants, ecological processes and natural features of this estuarine area [17]. 


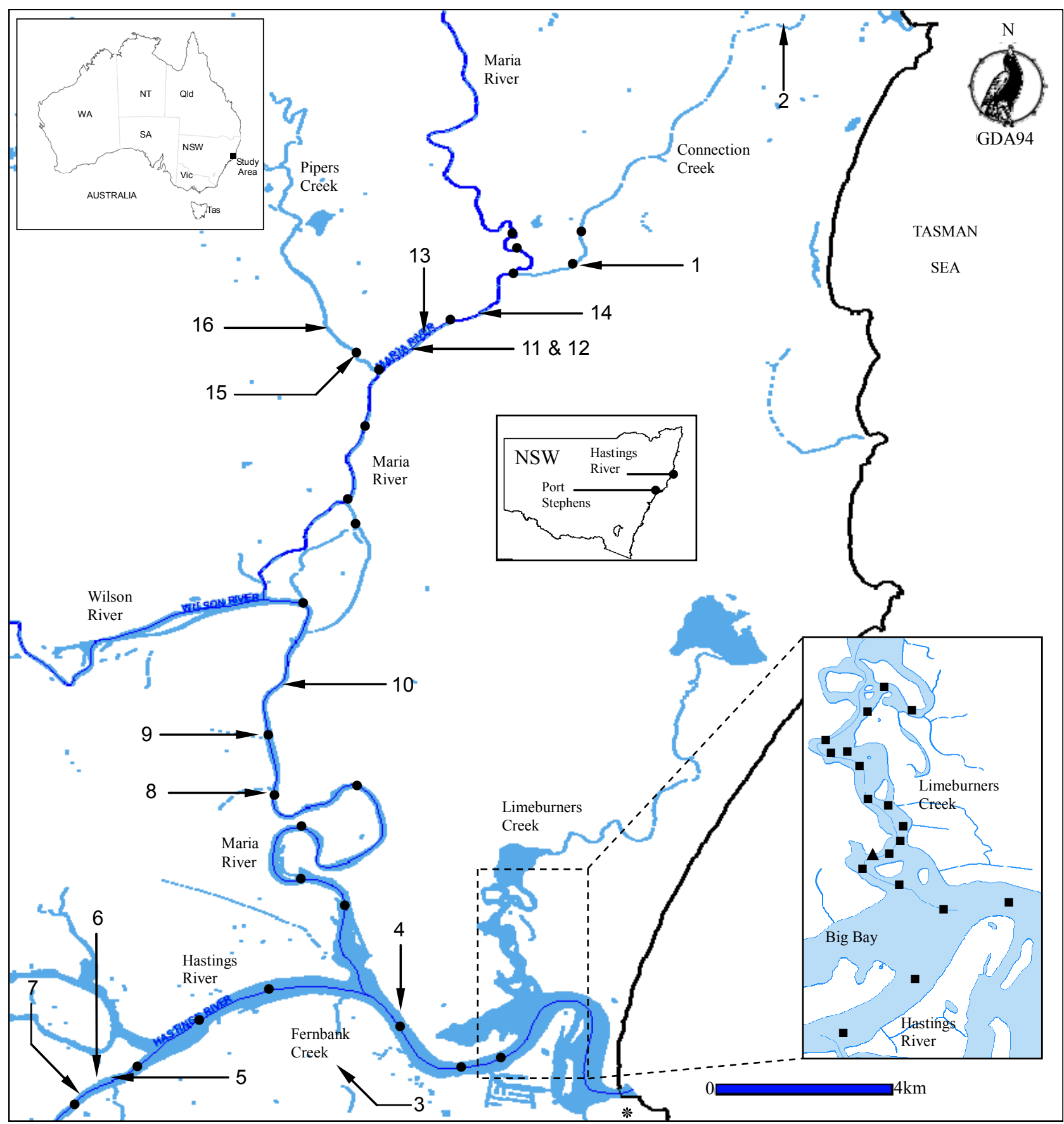

Figure 1. The Hastings River estuary, New South Wales (NSW). Regular water quality sampling sites in Hastings River and Limeburners Creek are displayed in the inset as squares ( $\square$ ). The site at which the submersible data logger was located is shown in the inset map as a triangle $(\Delta)$. Water quality sampling sites measured following rainfall displayed as circles $(\bullet)$. Arrows show the locations of acidic drains listed in Table 3. "*" symbol shows the location of Port Macquarie and the site of the Bureau of Meteorology Station Number 61026. Scale bar $=4 \mathrm{~km}$.

\section{Materials and Methods}

\subsection{Regular Sampling Locations and Dates: Hastings River and Limeburners Creek}

Regular in situ measurements of $\mathrm{pH}, \mathrm{EC}$ and temperature were taken from the centre of the channel of the Hastings
River and Limeburners Creek in the main commercial growing region for Sydney rock oysters. Sample sites are displayed in Figure 1 and sampling was conducted on the following dates: 17 Nov 1997; 4 Dec 1997; 20 Mar 98; 25 Mar 1998; 27 Mar 98; 2 Apr 1998; 17 Apr 1998; 27 Apr 1998; 4 May 1898; 15 May 1998; 2 Jun 1998; 5 


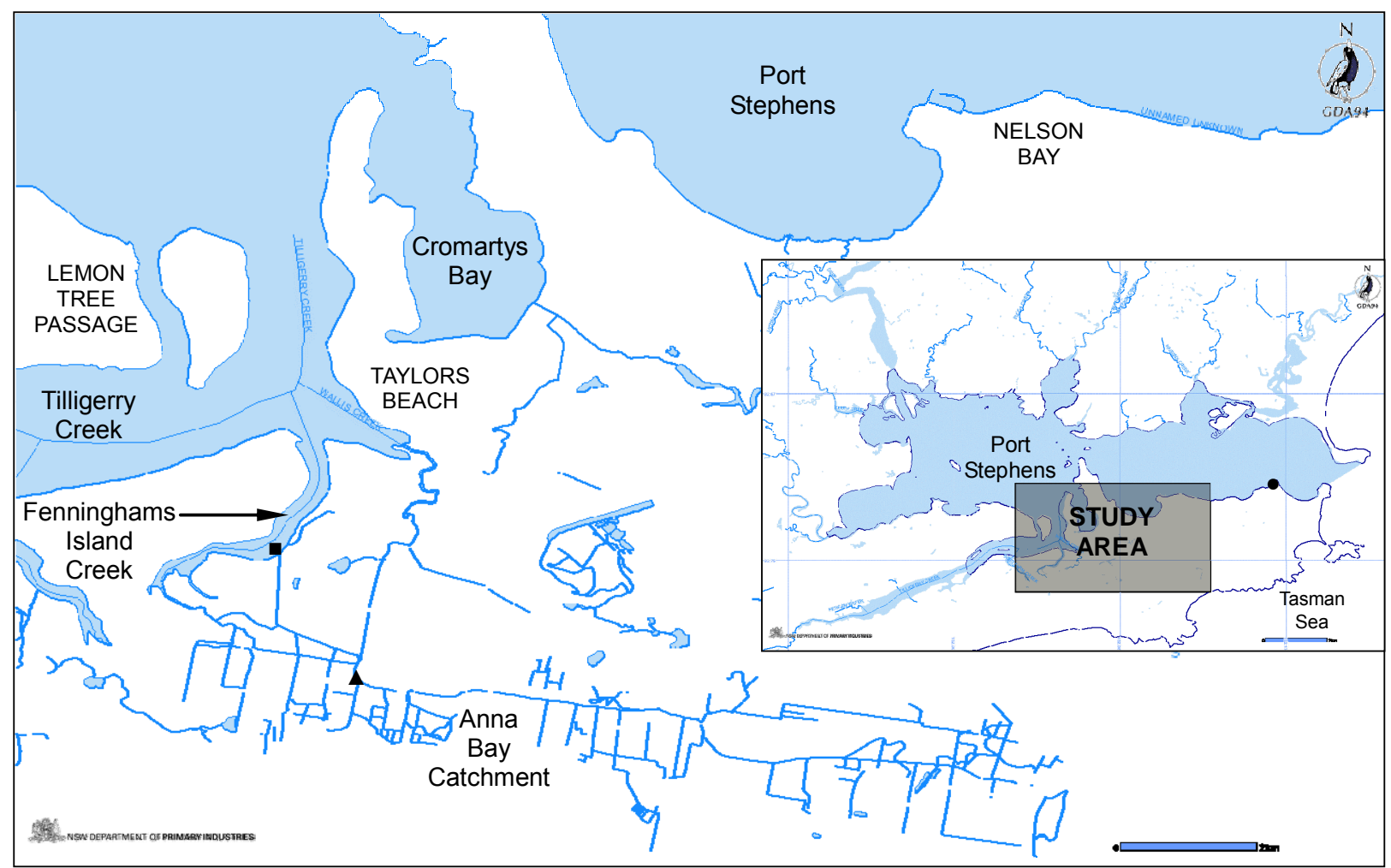

Figure 2. Port Stephens study area showing the locations of the submersible data logger ( $\square)$, the Anna Bay Drain floodgate $(\Delta)$ and Bureau of Meteorology Station Number $61054(\bullet)$. Scale bar $=2 \mathrm{~km}$.

Jun 1998; 21 Jul 1998; 31 Jul 1998; 10 Aug 1998; 17 Aug 1998; 31 Aug 1998; 15 Sep 1998; 1 Oct 1998; 16 Oct 1998; 9 Nov 1998; 7 Dec 1998; 25 Jan 1999; 4 Feb 1999; 4 Mar 1999; and, 30 Mar 1999 (Figure 3). Rainfall data were obtained from the Bureau of Meteorology (Station Number 60026) located at Port Macquarie (Figure 1).

\subsection{Sampling Locations and Dates Following Rainfall: Hastings River}

In situ measurements of $\mathrm{pH}$ and $\mathrm{EC}$ were taken at 16 floodplain drains and along the centreline of main channels of the Hastings River estuary approximately two weeks after heavy rainfall in the catchment (Figure 4). Sampling was done during the final quarter of the ebb tide.

Drains were sampled on the following dates: 18 June 1999; 29 November 1999; 1 December 2000; and, 12 February 2001 (Figure 4). Estuarine water quality was sampled on: 19 June 1999, 30 November 1999, 2 December 2000 and 13 February 2001. Estuarine and drain sample sites are displayed in Figure 1.

\subsection{Water Quality Measurements and Chemical Analyses: Hastings River}

A Yeo-Kal Intelligent Water Quality Analyser (Model
611) regularly calibrated with certified standard solutions was used for all discrete field measurements of water $\mathrm{pH}$, EC and temperature. A TPS Field Meter (MC80) with an Ionode (IJ 44) $\mathrm{KCl}$-filled intermediate junction $\mathrm{pH}$ probe calibrated with standard buffers was used to confirm the accuracy of $\mathrm{pH}$ measurements. A surface and bed measurement was performed at each of the estuarine water quality sites (Figure 1) where water depth was greater than $0.3 \mathrm{~m}$. Surface measurements were made at a depth of $0.1 \mathrm{~m}$ and bed measurements were made at $0.2 \mathrm{~m}$ above the substrate of the channel.

To examine the chemical composition of acidified drain outflows a water sample was collected in acidwashed, $0.5 \mathrm{~L}$ plastic containers and chilled and frozen for storage prior to analysis. Surface water samples were "gulp" sampled and bed waters were collected with a train of three biological-oxygen-demand bottles in series [18]. Water samples were filtered through $0.22 \mu \mathrm{m}$ cellulose nitrate filter paper (Catalogue number: GSWP02500, Millipore Corporation, Billerca, MA, USA) and analysed using Inductively coupled Plasma Atomic Excitation Spectroscopy (ICPAES) (Model: Perkin Elmer Optima $3000 \mathrm{DV}$ ) for dissolved Fe, Al, Mn, Si and Zn concentrations. Sulfate and chloride were also measured in samples using a modified version of the Turbidimetric Method [19] and the Potentiometric Method [19], respectively. 


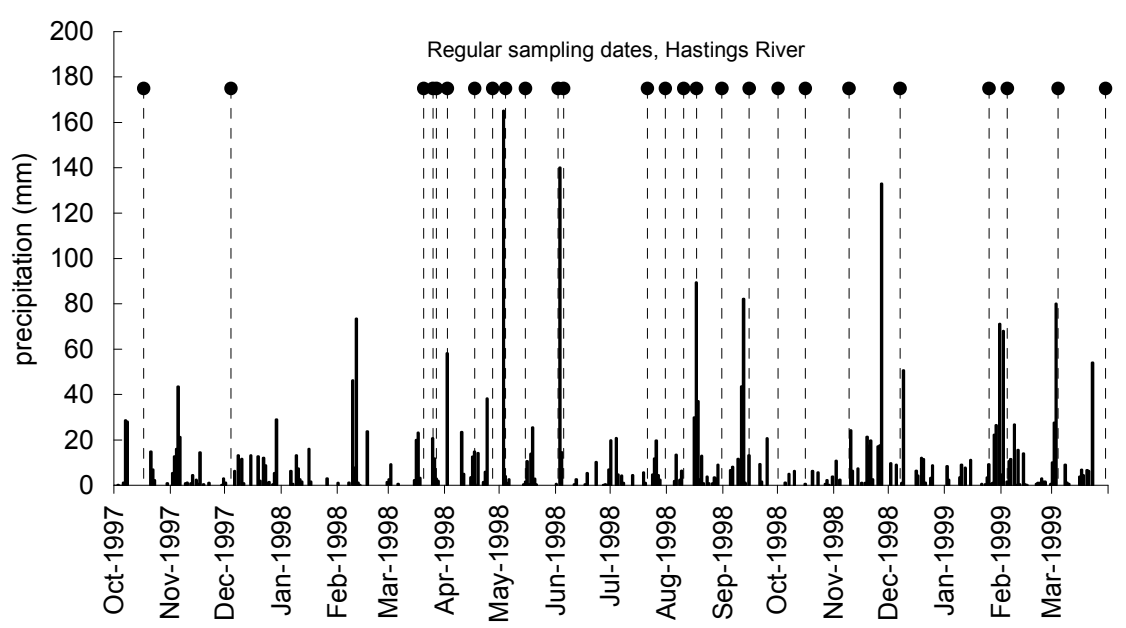

Figure 3. Rainfall recorded at Port Macquarie (Bureau of Meteorology Station Number 60026) for the period 1 October 1997 to the 31 March 1999 showing the regular sampling dates for Limeburners Creek and the lower Hastings River.

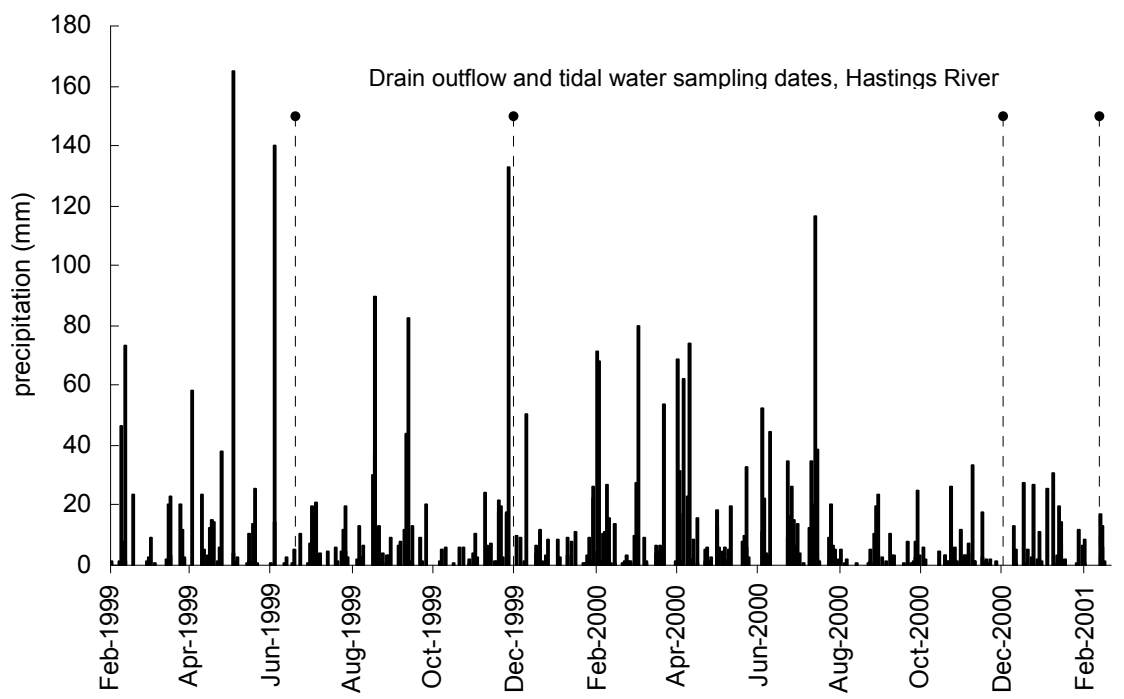

Figure 4. Rainfall recorded at Port Macquarie (Bureau of Meteorology Station Number 60026) for the period 1 February 1999 to the 16 February 2001 showing the tidal water and drain outflow sampling dates.

\subsection{Continuous Measurements of $\mathrm{pH}$ and Electrical Conductivity: Hastings River and Port Stephens}

Continuous time-series water quality measurements of $\mathrm{pH}, \mathrm{EC}$ and temperature were made by submersible data loggers (SDL). A Greenspan Technical Services Smart Sonde (Model SD 3000, Warwick, Queensland, Australia) was used on the Hastings River and an In-Situ Troll (Model 9500, Fort Collins, Colorado, USA) was used in Port Stephens. Both instruments were floated $0.2 \mathrm{~m}$ below the surface on oyster leases for periods of approximately three weeks and programmed to record $\mathrm{pH}, \mathrm{EC}$ and water temperature at intervals of approximately 20 min. After each sampling period, data on the SDL were downloaded and the instrument was cleaned and recalibrated prior to redeployment.
The Greenspan SDL was situated in Limeburners Creek (Figure 1) for the periods: 6 Nov 1997 to 2 Dec 1997; 4 Dec 1997 to 28 Dec 1997; 9 Apr 1998 to 25 May 1998; and, 11 Aug 1998 to 31 Aug 1998. The In-Situ Troll SDL was located on an Oyster Lease in Fenninghams Island Creek (Figure 2) and collected data from October 2007 to June 2008. Rainfall data related to sampling in Port Stephens were obtained from the Bureau of Meteorology (Nelson Bay, Station Number 61054) and are displayed in Figure 5.

\section{Results}

\section{1. pH, EC and Temperature Regular Sampling: Limeburners Creek and Hastings River}

The minimum $\mathrm{pH}$ measured during the regular sampling 


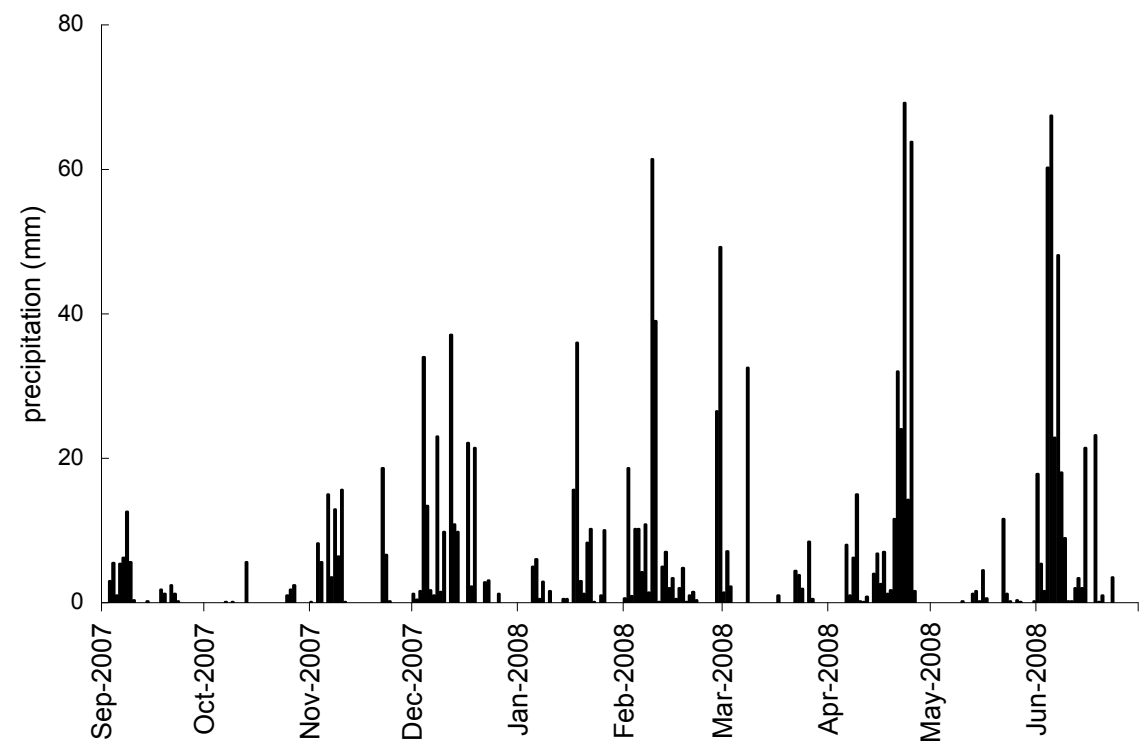

Figure 5. Rainfall recorded at Nelson Bay (Bureau of Meteorology Station Number 61054) relevant to Port Stephens for the period 1 September 2007 to 30 June 2008.

in the surface waters of Limeburners Creek was 6.31 at Site 19 on 5 June 1998. The minimum pH for bed waters of Limeburners Creek was 6.57 at Site 17 measured on the same date. This occurred immediately after a large rainfall event where $150 \mathrm{~mm}$ of rainfall was recorded in two days (Figure 3). This also resulted in EC levels in Limeburners Creek being depressed in both surface and bed waters. Figure 6 displays the $\mathrm{pH}$ and EC conditions during a period of low rainfall where both the $\mathrm{pH}$ and $\mathrm{EC}$ values were high and consistent with distance upstream on 4 December 1997 in Limeburners Creek. However, immediately after rainfall both $\mathrm{EC}$ and $\mathrm{pH}$ decreased with increasing distance upstream in Limeburners Creek (Figure 7).

The minimum $\mathrm{pH}$ measured in surface waters of the main channel of the Hastings River during regular sampling was 7.05 on 15 September 1998. Figure 8 shows the difference in $\mathrm{pH}$ between surface and bed waters resulting from density stratification at the four sampling sites in the lower Hastings River.

The minimum EC in Limeburners Creek $\left(0.9 \mathrm{dS} \cdot \mathrm{m}^{-1}\right)$ was measured in the surface waters at the site furthest upstream on 5 June 1998 (Figure 7) and the minimum EC level measured in the lower Hastings River occurred on 17 August 1998 (Figure 8) for surface waters and 2 June 1998 for bed waters $\left(3.8\right.$ and $25.4 \mathrm{dS} \cdot \mathrm{m}^{-1}$, respectively). The maximum EC level measured in Limeburners Creek during the study was $62.1 \mathrm{dS} \cdot \mathrm{m}^{-1}$. This EC value was measured on 7 December 1998 in both the surface and bed waters.

Water temperatures at the regular sample sites ranged from a minimum of $10.6^{\circ} \mathrm{C}$ at Site 16 on 5 June 1998 to $29.6^{\circ} \mathrm{C}$ at Sites 18 and 19 on 4 March 1999. The mini- mum temperature was measured in the bed waters and the maximum temperature was measured in the surface waters.

\subsection{SDL Measurements}

The $\mathrm{pH}, \mathrm{EC}$ and temperature data collected by the two SDLs are summarised in Table 1. The median $\mathrm{pH}, \mathrm{EC}$ and temperature value in the Hastings River was 8.07, $44.25 \mathrm{dS} \cdot \mathrm{m}^{-1}$ and $22.03^{\circ} \mathrm{C}$, respectively (Table 1). Influx of fresh water following rainfall caused the $\mathrm{pH}$ to fall below 7 on several occasions in the middle of September 1998. The minimum $\mathrm{pH}$ measured at this site was 6.9 on 13 September 1999.

The $\mathrm{pH}$ and EC data measured in Fenninghams Island Creek are displayed in Figure 9. Long-term continuous sampling at Fenninghams Island Creek revealed highly variable water quality conditions dependant on the tide, conditions in the Anna Bay drain and antecedent climatic conditions. Twice as much rain fell in the months of February to June (924 mm) compared to the period September through to the end of January $(451 \mathrm{~mm})$. EC data between 1 November 2007 and 15 February 2008 were discarded due to erroneous readings caused by iron floccules settling within the barrel of the EC probe. This problem was rectified by regular removal of fouling organisms from the cage containing this SDL.

During the period from the start of October to the end of December the minimum $\mathrm{pH}$ value recorded was 6.0 on 19 December 2007 and the $\mathrm{pH}$ dropped below 6.5 on the following dates: 9-13 November, 14-15 December and 17-24 December. More intense rainfall through late January and early February caused $\mathrm{pH}$ levels to fall and 


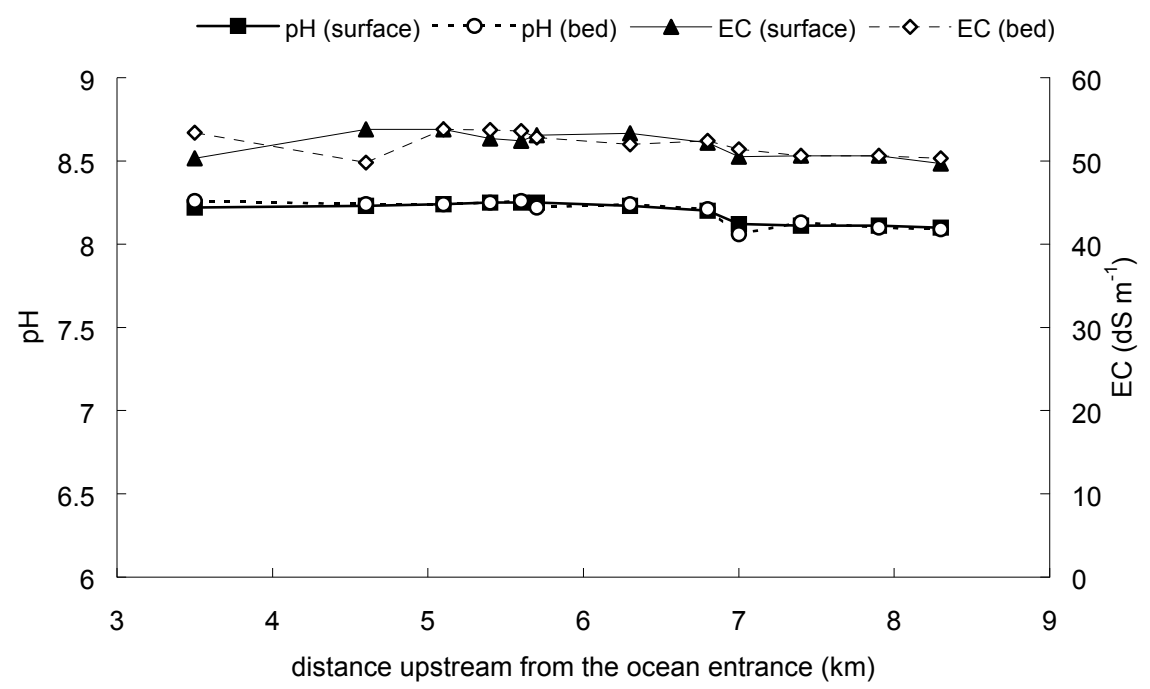

Figure 6. EC and pH in Limeburners Creek surface water and bed water prior to high rainfall on 4 December 1997.

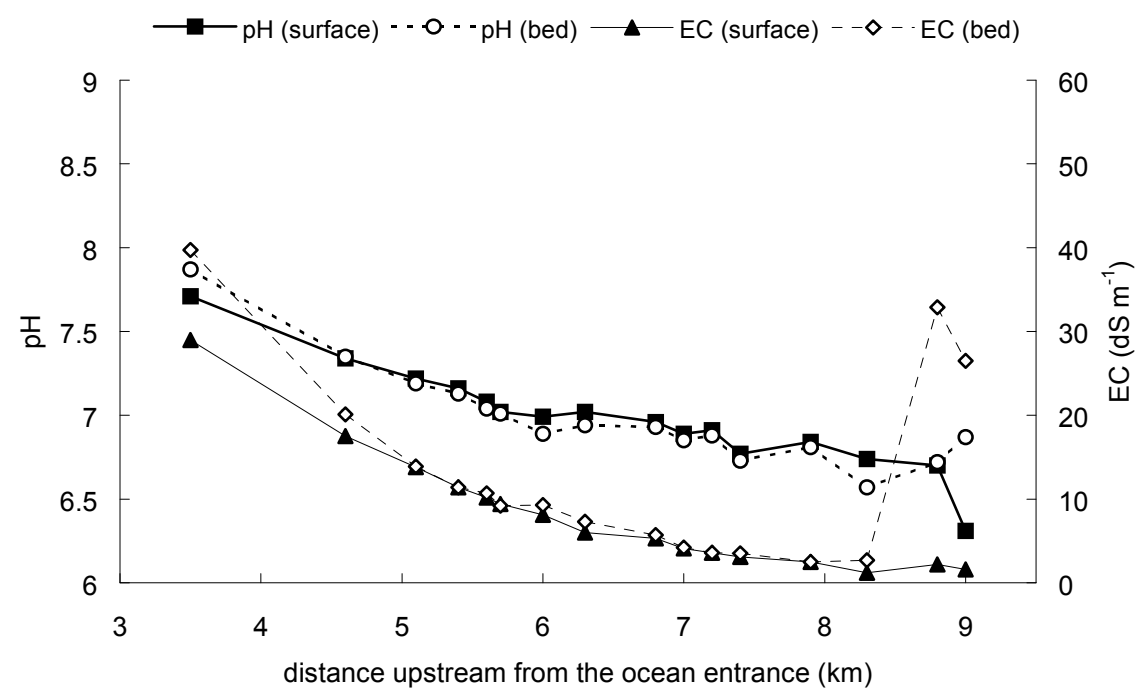

Figure 7. EC and pH in Limeburners Creek surface water and bed water after high rainfall on 5 June 1998.

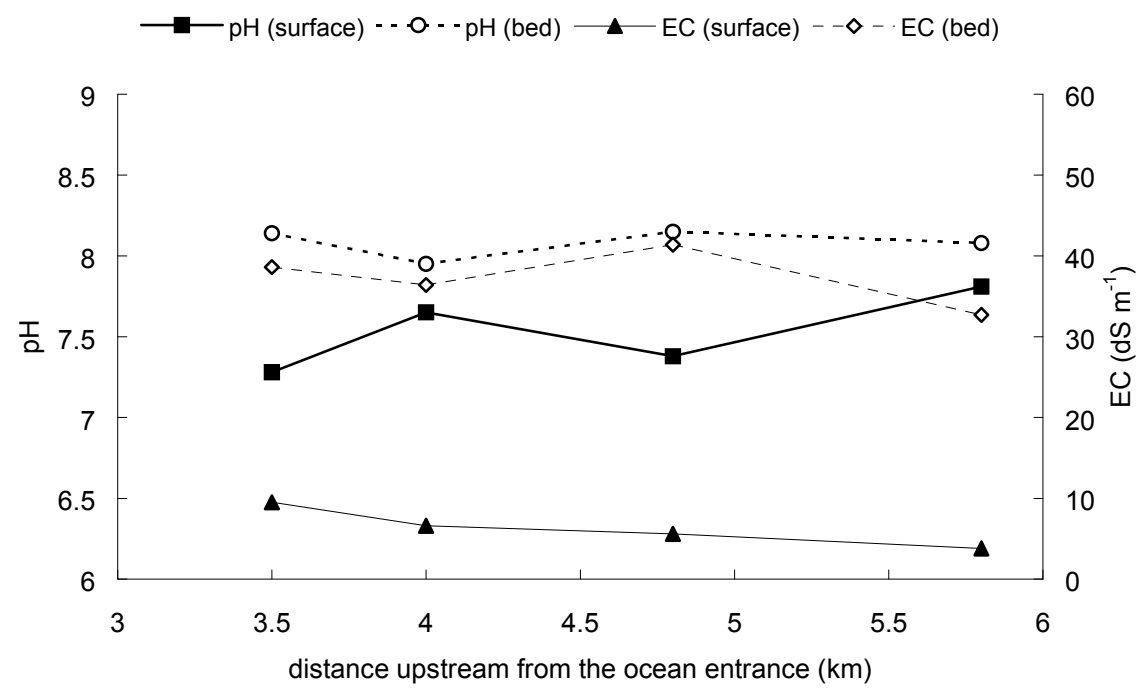

Figure 8. EC and pH stratification in the lower Hastings River prior to high rainfall on 17 August 1998. 
Table 1. Summary of pH, EC and temperature data collected by the SDL at Site A and Site B.

\begin{tabular}{|c|c|c|c|c|c|c|}
\hline & \multicolumn{3}{|c|}{ Hastings River } & \multicolumn{3}{|c|}{ Port Stephens } \\
\hline & $\mathrm{pH}(\mathrm{n}=10,396)$ & $\begin{array}{l}\mathrm{EC}\left(\mathrm{dS} \cdot \mathrm{m}^{-1}\right) \\
(\mathrm{n}=13,692)\end{array}$ & $\begin{array}{c}\text { Temp. }\left({ }^{\circ} \mathrm{C}\right) \\
(\mathrm{n}=13,692)\end{array}$ & $\mathrm{pH}(\mathrm{n}=15,402)$ & $\begin{array}{c}\mathrm{EC}\left(\mathrm{dS} \cdot \mathrm{m}^{-1}\right) \\
(\mathrm{n}=9,094)\end{array}$ & $\begin{array}{c}\text { Temp. }\left({ }^{\circ} \mathrm{C}\right) \\
(\mathrm{n}=15,402)\end{array}$ \\
\hline Minimum & 6.86 & 3.30 & 15.32 & 4.31 & 1.76 & 11.88 \\
\hline Maximum & 9.00 & 56.25 & 29.64 & 8.44 & 60.95 & 31.60 \\
\hline Median & 8.07 & 44.25 & 22.03 & 7.28 & 38.60 & 22.86 \\
\hline Mean & - & 39.72 & 22.00 & - & 34.48 & 21.83 \\
\hline Standard Dev. & - & 12.26 & 2.58 & - & 14.86 & 4.03 \\
\hline
\end{tabular}

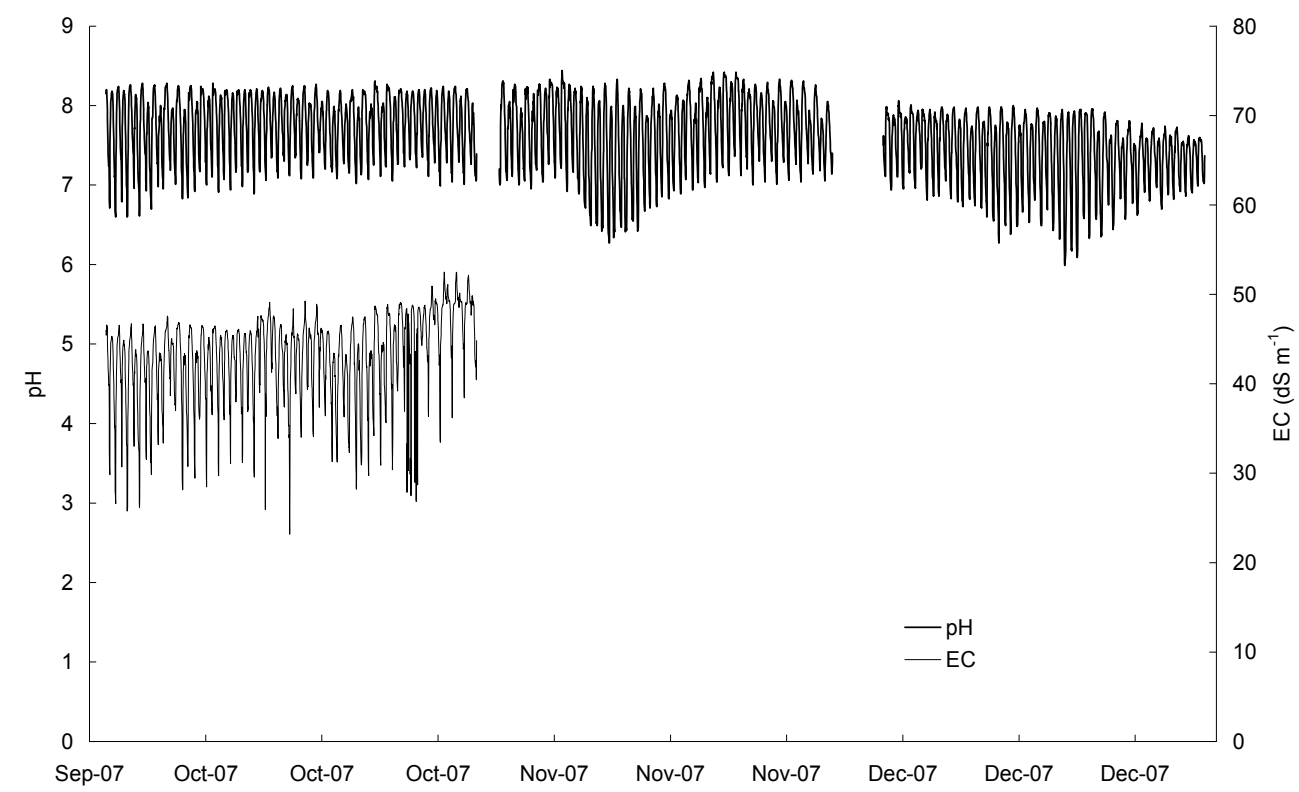

(a)

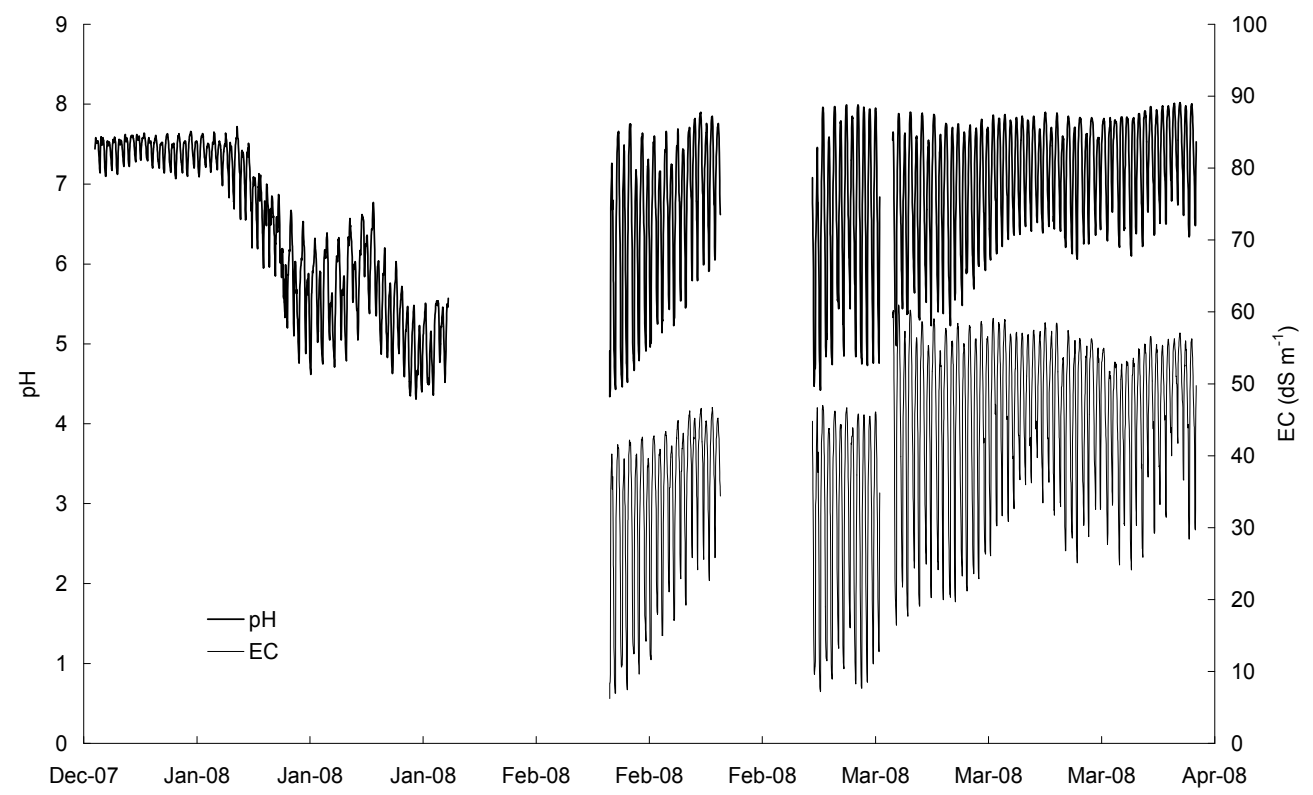

(b) 


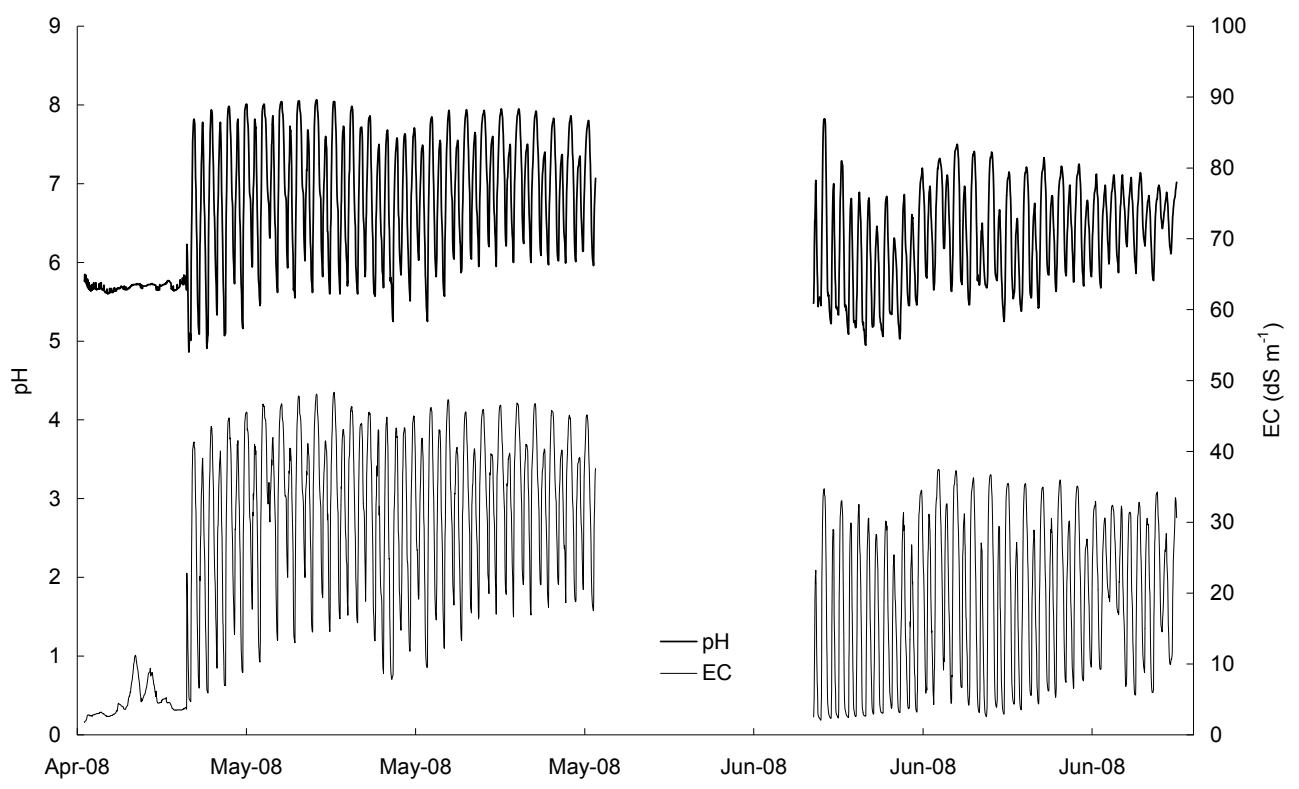

(c)

Figure 9. pH and EC from the In-Situ submersible data logger from: (a) October to December 2007; (b) January to early April 2008; and (c) Late April to June 2008. Some EC data are missing due to probe fouling.

pHs below 5 were commonly measured during the final stages of the ebb tide and early stages of the flood tide.

Three substantial rain events caused the $\mathrm{pH}$ to decrease at the lease site during the monitoring period. In early February, $157 \mathrm{~mm}$ of rainfall was recorded in eight days. In late April, $214 \mathrm{~mm}$ of rainfall was measured over five days and in the first nine days of June, $250 \mathrm{~mm}$ of rainfall was recorded. Immediately following these rain events the initial outflow water had circumneutral $\mathrm{pH}$ levels: the $\mathrm{pH}$ then incrementally declined at the base of the ebb tide. This was due to runoff from recent rainfall diluting the acidified drain outflows, then, as base flows commenced the $\mathrm{pH}$ rapidly decreased at the lease site. Following rain events the $\mathrm{pH}$ declined and could fall to below 5 during the last stage of the ebb tide for periods lasting more than 3 weeks. EC levels also varied considerably following these rain events due to the influence of fresh drain-outflow water on the ebb tide and saline estuary water moving back to the site during the flood tide.

\subsection{Drain Outflow Water Quality Following Rainfall}

The $\mathrm{pH}$ values of drains discharging into the Hastings and Maria Rivers collected during the four sampling occasions are summarised in Table 2 . The $\mathrm{pH}$ values measured at drain outflow locations and estuarine sites on 18-19 June 1999 are displayed in Figures 10 and 11.

Table 3 lists $\mathrm{pH}, \mathrm{EC}$, iron, aluminium manganese, silicon, zinc and $\mathrm{Cl}: \mathrm{SO}_{4}$ data for selected drains that flow into the Hastings River estuary. All drains listed in Table 3, with the exception of Drain 7, have a low $\mathrm{pH}$ com- bined with a $\mathrm{Cl}: \mathrm{SO}_{4}$ ratio of less than 4. Additionally, Drain 7 had very high concentrations of aluminium $\left(19.40 \mathrm{mg} \cdot \mathrm{L}^{-1}\right)$, iron $\left(33.90 \mathrm{mg} \cdot \mathrm{L}^{-1}\right)$, manganese $(2.30$ $\left.\mathrm{mg} \cdot \mathrm{L}^{-1}\right)$ and zinc $\left(0.47 \mathrm{mg} \cdot \mathrm{L}^{-1}\right)$.

\subsection{Estuarine Water Quality Following Rainfall}

Water $\mathrm{pH}$ and EC decreased with increasing distance upstream in the Hastings River channel (Figure 10). The $\mathrm{pH}$ dropped below neutral in the surface waters at the centre of the main channel close to the drain outflow locations.

Low EC values were measured in the Maria River system following the June rainfall event due to the dominance of floodwaters in the system (Figure 11). The decrease of $\mathrm{pH}$ in the main channel of the Maria River was pronounced and caused by acidic water discharging from drains on the Maria River floodplain.

The extent of iron and aluminium precipitate distribution was observed during each sampling date and on other occasions following rainfall. The primary sources of iron flocs entering the main channel of the Hastings River were from Fernbank Creek, Maria River, and Drains 4, 5, 6 and 7 (Table 3). Aluminium flocs were commonly observed in Fernbank Creek outflows.

Iron flocs contaminated the near-shore downstream reach of the confluence of the Hastings River and Fernbank Creek for a distance of $2.5 \mathrm{~km}$ after high rainfall. Similarly, iron flocs originating from drains in the Maria River smothered more than $3 \mathrm{~km}$ of the northern bank of the Hastings River. This occurred after a flood event where $187 \mathrm{~mm}$ of rainfall was recorded in 10 days. 
Table 2. Summary of Hastings River estuary drain outflow pH data on the four sampling occasions.

\begin{tabular}{ccccc}
\hline & 18-19 June 1999 & 29-30 November 1999 & 1-2 December 2000 & 35 \\
\hline No. of Drains Sampled & 38 & 31 & 39 \\
Min. pH & 3.35 & 3.16 & 2.72 & 2.81 \\
Max. pH & 8.00 & 7.50 & 7.20 & 7.24 \\
Median pH & 6.01 & 6.15 & 6.15 \\
\hline
\end{tabular}

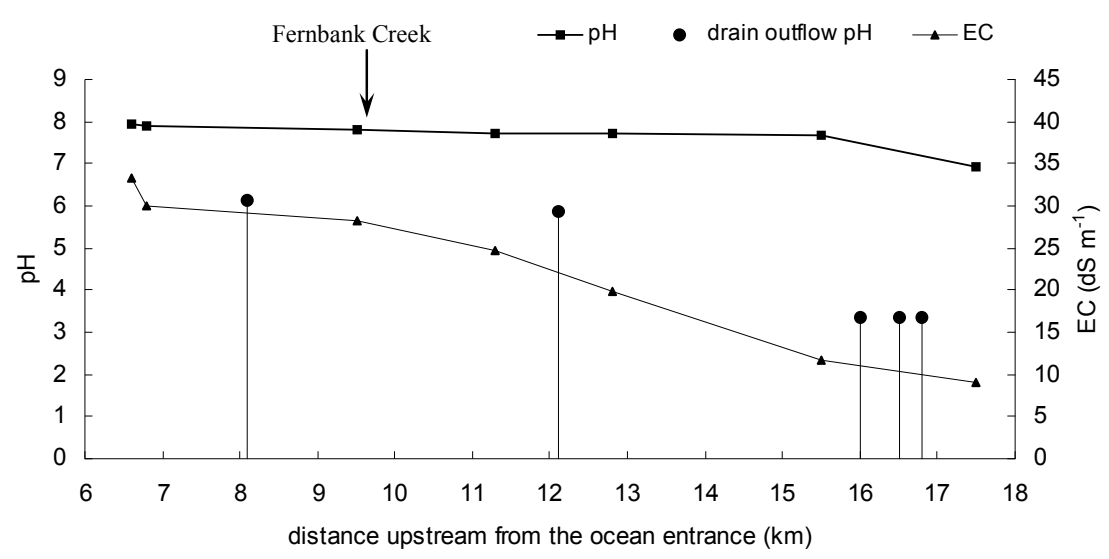

Figure 10. Hastings River surface water pH, EC and drain outflow pH measured on 18 and 19 June 1999.

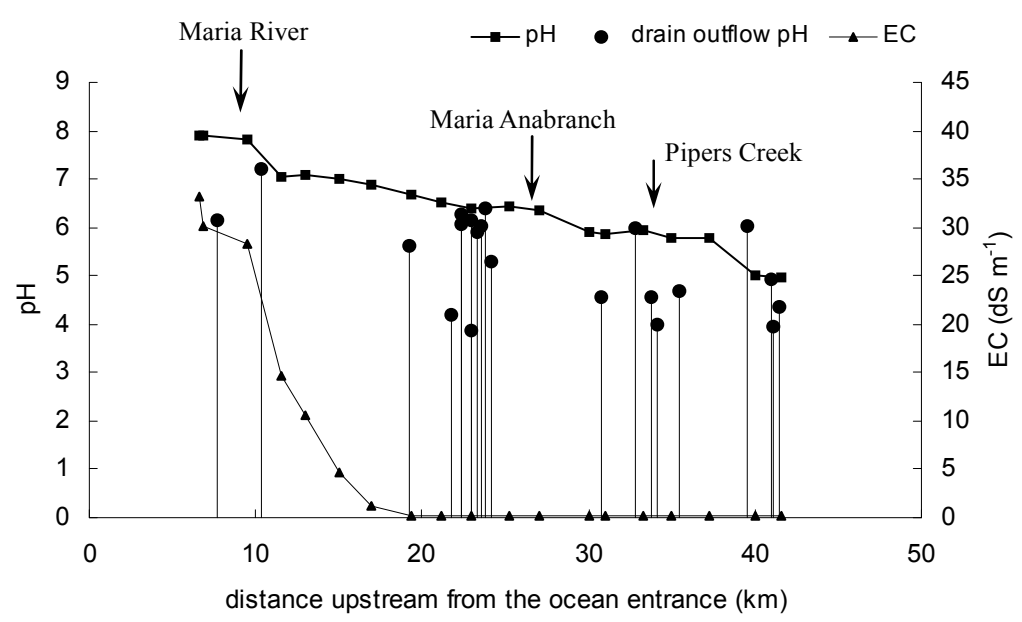

Figure 11. Hastings/Maria River surface water pH, EC and drain outflow pH measured on 18 and 19 June 1999.

\section{Discussion}

The lower region of the Hastings River estuary did not experience estuarine acidification caused by acidic outflows during the field study. However, areas further upstream in the Hastings and Maria River systems were impacted by estuarine acidification.

In the lower reaches of the Hastings River and Limeburners Creek, EC suppression occurred over short periods of time and brackish estuary conditions rapidly returned after the rainfall had ceased because this area was close to the ocean entrance thereby increasing the amount of strongly-buffered oceanic water and tidal mixing.
Stratification resulting from EC differences between surface and bed waters was typical in the main channel of the Hastings River (Figure 8) and was more pronounced than in Limeburners Creek. Similar effects were observed by Sammut et al. [6] in a northern NSW estuary.

$\mathrm{Cl}: \mathrm{SO}_{4}$ ratios were greater than 5 and the minimum $\mathrm{pH}$ values measured were greater than 6 on all occasions during the study period in Limeburners Creek which indicates that the estuarine waters were not affected by sulfate released from ASS [20]. However, $\mathrm{pH}$ was reduced to a level slightly below $\mathrm{pH} 7$ after high rainfall (Figure 7). 
Table 3. Water quality of selected Hastings River estuary drain outflows. Drain locations are displayed in Figure 1.

\begin{tabular}{|c|c|c|c|c|c|c|c|c|c|c|}
\hline Drain No. & Drain ID & Date & $\mathrm{pH}$ & $\mathrm{EC}\left(\mathrm{dS} \cdot \mathrm{m}^{-1}\right)$ & $\mathrm{Fe}\left(\mathrm{mg} \cdot \mathrm{L}^{-1}\right)$ & $\mathrm{Al}\left(\mathrm{mg} \cdot \mathrm{L}^{-1}\right)$ & $\operatorname{Mn}\left(m g \cdot L^{-1}\right)$ & $\mathrm{Si}\left(\mathrm{mg} \cdot \mathrm{L}^{-1}\right)$ & $\mathrm{Zn}\left(\mathrm{mg} \cdot \mathrm{L}^{-1}\right)$ & $\mathrm{Cl}: \mathrm{SO}_{4}$ \\
\hline \multicolumn{11}{|c|}{ Connection Creek } \\
\hline 1 & $\mathrm{CC} 38.4 \mathrm{R}$ & $13 / 02 / 01$ & 3.19 & 0.9 & 7.75 & 2.27 & 0.38 & 6.39 & 0.10 & 1.1 \\
\hline 2 & $\mathrm{CC} 44.1 \mathrm{R}$ & $13 / 02 / 01$ & 3.58 & 1.0 & 36.70 & 1.37 & 0.53 & 6.52 & 0.10 & 0.5 \\
\hline \multicolumn{11}{|c|}{ Fernbank Creek } \\
\hline 3 & FC11.6L & $13 / 02 / 01$ & 3.28 & 1.3 & 35.90 & 1.84 & 0.40 & 10.30 & 0.06 & 1.3 \\
\hline \multicolumn{11}{|c|}{ Hastings River } \\
\hline 4 & HR08.1R & $13 / 02 / 01$ & 4.10 & 1.1 & 12.20 & 0.46 & 0.16 & 4.60 & 0.03 & 3.8 \\
\hline 5 & HR16.0R & $12 / 02 / 01$ & 2.81 & 5.9 & 48.10 & 9.53 & 1.45 & 15.80 & 0.23 & 1.6 \\
\hline 6 & HR16.5R & $18 / 06 / 99$ & 3.37 & 2.7 & 4.03 & 8.34 & 1.22 & 12.15 & ND & 2.8 \\
\hline 7 & HR16.8R & $12 / 02 / 01$ & 3.48 & 8.8 & 33.90 & 19.40 & 2.30 & 17.90 & 0.47 & 4.4 \\
\hline \multicolumn{11}{|c|}{ Maria River } \\
\hline 8 & MR21.7L & $01 / 12 / 00$ & 3.19 & 1.6 & 1.27 & 7.37 & 0.58 & 8.98 & 0.11 & 2.4 \\
\hline 9 & MR23.0L & $30 / 11 / 99$ & 3.64 & 3.5 & 2.54 & 2.73 & 0.66 & 5.28 & ND & 3.6 \\
\hline 10 & MR24.2R & $12 / 02 / 01$ & 3.83 & 3.2 & 0.98 & 2.19 & 0.34 & 6.44 & 0.05 & 3.0 \\
\hline 11 & MR33.8R(A) & $13 / 02 / 01$ & 3.06 & 1.9 & 8.02 & 5.34 & 0.56 & 5.84 & 0.13 & 1.0 \\
\hline 12 & MR33.8R(B) & $02 / 12 / 00$ & 2.77 & 2.4 & 11.40 & 4.43 & 0.57 & 2.18 & 0.12 & 1.1 \\
\hline 13 & MR34.1R & $02 / 12 / 00$ & 3.20 & 2.4 & 3.22 & 20.70 & 1.47 & 3.65 & 0.25 & 0.9 \\
\hline 14 & MR35.5R & $02 / 12 / 00$ & 2.91 & 5.3 & 15.30 & 2.08 & 0.31 & 5.51 & 0.05 & 2.6 \\
\hline \multicolumn{11}{|c|}{ Pipers Creek } \\
\hline 15 & PC $34.5 \mathrm{~L}$ & $12 / 02 / 01$ & 3.47 & 1.1 & 2.80 & 1.58 & 0.36 & 4.36 & 0.06 & 2.1 \\
\hline 16 & PC34.7L & $18 / 06 / 99$ & 4.29 & 0.7 & 0.32 & 1.60 & 0.13 & 10.10 & ND & 2.2 \\
\hline
\end{tabular}

In the upstream areas of the Hastings and Maria River systems, rainfall was a principal factor in the mobilisation of ASS oxidation products from the Hastings River floodplain. After periods of heavy rainfall poor water quality conditions existed in the Maria River, Connection Creek and Fernbank Creek. Water discharging from floodplain drains was acidified and had elevated concentrations of toxic metals. A Cl: $\mathrm{SO}_{4}$ ratio of less than 4 and $\mathrm{pH}$ values less than 4 indicate mineral acidity rather than naturally occurring humic acids due to the release of sulfate during pyrite oxidation [20]. Sulfate, released from pyrite oxidation, reduces the $\mathrm{Cl}: \mathrm{SO}_{4}$ although secondary acidification from the oxidation of iron and hydrolysis of aluminium may also drive the $\mathrm{pH}$ down further [21].

The decrease in $\mathrm{pH}$ and $\mathrm{EC}$ with increasing distance upstream is attributable to neutral, poorly-buffered, freshwater inflows from the upper catchment in combination with acidic outflows from floodplain drains 15 17 kilometres upstream from the Hastings River entrance
(Figure 10). Floodgates and artificial drainage systems present on the Hastings River floodplain facilitate acid production and export, as well as attenuate or completely restrict tidal ingress that would otherwise buffer the $\mathrm{pH}$ within the drains.

The drain density and drain volume in the upper reaches of the Maria River $(>20 \mathrm{~km}$ upstream from the Hastings River entrance) and Connection Creek (Figure 1) are high compared to other areas of the Hastings River estuary $[12,13]$. The drainage systems in these areas can efficiently export large volumes of fresh, acidic water containing elevated concentrations of iron and aluminium into the main channel.

Floodgates can store acidified water in floodplain drains for prolonged periods $[6,13]$. The stored acid is released during the ebb tide when the hydraulic head of the drains is higher than the tidal reach; the floodgate opens when this occurs and closes on high tide when the pressure of the tidal water forces the gates to close. Un- 
der dry weather conditions, when tidal waters are well buffered, the ebb tide pulses of acidic water were neutralised close to the outflow point, but iron flocs can nevertheless travel for many kilometres downstream. By contrast, wet weather can deplete the acid neutralising capacity of tidal waters and increase acid outflows from floodgates leading to acidification of tidal reaches [6]. Acid may also move up and down the river during wet weather due to plug-flow displacement from the drains. Density differences between acid water and tidal water can result in an upstream and downstream movement of an acid plug [6].

The temporal persistence of acid events in Maria River and Fernbank Creek is dependant upon the intensity of the rainfall event and the duration of the interim dry (or low rainfall) period $[13,22,23]$. Johnston [13] reported that acidic conditions $(<\mathrm{pH} 5.5)$ persist for 4 to 6 weeks in the upper reaches of the Maria River. Manly Hydraulics Lab [22] measured a pH of approximately 6.6 continuing from October 1994 to January 1995 in the Maria River at Green Valley and in Connection Creek (32.2 and $42.5 \mathrm{~km}$ upstream from the Hastings River entrance respectively).

A long-term pattern of acidic discharges also occurred at the Fenninghams Island Creek site in Port Stephens. Large volumes of fresh, circumneutral water flows through oyster leases immediately following heavy rainfall. This was mostly surface waters that quickly drained from the catchment through the drainage network. Once surfacewater flows are depleted, more acidic water that has interacted with oxidised sediments enters the drain causing a rapid drop in $\mathrm{pH}$ [14]. This water discharged during each ebb tide cycle causing low $\mathrm{pH}$ and $\mathrm{EC}$ conditions at the base of the ebb tide on oyster leases. $\mathrm{EC}$ and $\mathrm{pH}$ then increased as saline estuary waters moved back to the monitoring site during the flood tide and displaced and/or neutralised the drain water. Although, $\mathrm{pH}$ and EC conditions improve for oysters at this stage of the tidal cycle, high concentrations of iron and aluminium flocs were observed to be still present at this site. It is likely that the oysters will then filter these flocs out of the water column and ingest them [8].

Concentrations of metals measured in particular drains of the Hastings River exceed the threshold values of the Australian and New Zealand Environment and Conservation Council (ANZECC) guidelines for the maintenance of water quality for biological systems [24]. This study and previous studies $[13,23]$ have measured extremely high concentrations of iron and aluminium. Johnston [13] measured an aluminium concentration of $3.06 \mathrm{mg} \cdot \mathrm{L}^{-1}$ and ERM Mitchell McCotter [23] measured $20 \mathrm{mg} \cdot \mathrm{L}^{-1}$ of aluminium and $14 \mathrm{mg} \cdot \mathrm{L}^{-1}$ of iron at the Partridge Creek drain discharging into Fernbank Creek. The maximum concentration of iron and aluminium measured at Fern- bank Creek during this study was $35.90 \mathrm{mg} \cdot \mathrm{L}^{-1}$ and $13.84 \mathrm{mg} \cdot \mathrm{L}^{-1}$, respectively.

Very high aluminium and iron concentrations were also measured in Port Stephens after rainfall in June 2006 [25]. Acidic ( $\mathrm{pH} 3.3$ ) drain water containing very high concentrations of both iron $\left(70.65 \mathrm{mg} \cdot \mathrm{L}^{-1}\right)$ and aluminium $\left(60.40 \mathrm{mg} \cdot \mathrm{L}^{-1}\right)$ was measured discharging through the floodgate. Consequently, the surface waters of Fenninghams Island Creek had elevated aluminium (5.76 $\left.\mathrm{mg} \cdot \mathrm{L}^{-1}\right)$ and iron $\left(9.75 \mathrm{mg} \cdot \mathrm{L}^{-1}\right)$ concentrations [25].

The extent of estuarine acidification on the Hastings River estuary and the damage from long-term, twicedaily acid water discharges into the estuary that was measured at Port Stephens has implications for oyster health as well as other aquatic life. Furthermore, ASS oxidation products, namely iron and aluminium, are distributed in circumneutral waters well beyond the acidified areas and into oyster producing areas. The following section discusses the implications of these physical and chemical changes in estuarine water for oyster production.

\section{Implications for Sydney Rock Oyster Production}

Many marine and estuarine algae, bacteria and animal species have a very low tolerance to $\mathrm{pH}$ reductions [26]. American research has found that a number of bivalve species are unable to tolerate $\mathrm{pH}$ levels below $7[27,28]$ and have also shown that only 0.5 unit changes in $\mathrm{pH}$ result in impacts to bivalves [27-29,30]. Wilson and Hyne [9] used bioassay experiments to show that ASSaffected waters, weakly acidified water $(\mathrm{pH}$ 6.75) and water containing aluminium $\left(150 \mu \mathrm{m} \cdot \mathrm{L}^{-1}\right)$ caused abnormal embryonic development in S. glomerata. More recent research has shown that fertilisation success and embryonic development in Sydney rock oysters is significantly affected by very minor $\mathrm{pH}$ decreases [10]. Other studies have recently investigated the effects of carbon dioxide-induced seawater acidification to bivalves $[31,32]$. These studies further confirmed that only very small decreases in ocean-water $\mathrm{pH}$ have profound consequences for bivalve's life processes. This present study showed that although acidification of estuarine waters was localised, the level of acidification is many orders of magnitude greater than investigated in studies looking at the effects of seawater acidification resulting from increased carbon dioxide concentrations in the earth's atmosphere.

$\mathrm{pH}$ levels and metal concentrations are determining factors for fish kills $[11,33]$. Under chronic acidic conditions moderately weak acidity was more likely to cause environmental impact than during acute, short-lived events. Areas of the Manning River, NSW which experienced long periods of weakly acidic conditions had 
significantly higher Sydney rock oyster mortality rates than areas with short duration tidal pulse-flows of acidic water which resulted in widely variable $\mathrm{pH}$ and conductivity levels [1].

When oysters are exposed to acidified water changes initially occur to the valves' appearance [1]. The iron in ASS-affected water coats the oyster shell making it appear an ochre red colour. Acidified waters bleach the external shell surface and cause the shell to become brittle and weak. Extended periods of exposure ( $>25$ days) to chronically weak acid conditions causes shell perforation in the dorsal section of the left valve [1].

Internal shell dissolution can also be induced by prolonged exposure to ASS-affected waters. Oysters respond to acidified and fresh waters by remaining closed [8]. When oyster valves are closed, the carbon dioxide produced by an oyster decreases the $\mathrm{pH}$ of the hemolymph [34]. Morrison [35] reported that shell dissolution of internal valve surface occurs in anaerobic conditions, when acid forms as a result of metabolism and dissolve intracellular deposits of calcium carbonate in the mantle and inside of the shell. Dwyer and Burnett [36] described this process as shell decalcification and results in internal shell dissolution.

High concentrations of dissolved and colloidal metals have implications for Sydney rock oyster health. Dove and Sammut [1] discovered that iron and aluminium, contained in ASS-affected water, contributed to the high mortality and reduced growth rates in oysters at impacted sites on the Manning River, NSW. Iron accumulates on the gills and mantle and in the stomach, intestine, digestive tubules and rectum of oysters as well as congesting the ciliary junctions of the gills [8]. This is likely to impair primary gill functions such as feeding and gas exchange.

Dove [37] measured total particulate matter (TPM), particulate inorganic matter (PIM) and particulate organic matter (POM) of ASS-affected water in the Hastings River estuary. TPM and PIM was 28 and 21.5 $\mathrm{mg} \cdot \mathrm{L}^{-1}$, respectively, at an acidified oyster lease located downstream of the Fernbank Creek and Hastings River confluence. High concentrations of colloidal iron and aluminium alter the ratio between the inorganic component and the organic component of ASS-affected waters. This equates to a low organic content, or a small proportion of food, and a large proportion of non-utilisable matter within the available seston [38]. Therefore, the nutritional quality of ASS-affected waters is low when quality is expressed as organic content per unit volume of diet.

Oyster leases in the Maria River and near Fernbank Creek were not used to grow oysters during this study and most were in a degraded state indicating that oyster production had not occurred there for many years prior to this study. Oyster lease infrastructure (racking used to support oyster trays) in the Maria River system and downstream of Fernbank Creek on the southern bank of the Hastings River were coated with iron precipitates. Most leases in Fenninghams Island Creek were stocked with oysters during the period of monitoring in Port Stephens, however oyster farmers were advised to move stock after rainfall in early February to avoid exposing stock to acidified water. Oyster farmers do not always have alternative sites to culture oysters and there are labour and fuel expenses associated with moving oyster stock, particularly if the farming method is not designed for movement (e.g. stick culture). A number of leases in Fenninghams Island Creek, including the one used as the site for monitoring, were not used to grow oysters during the monitoring period. Recurrent acidification of these areas in the Hastings River and Port Stephens is a plausible explanation for the abandonment of these oyster leases for oyster production.

Estuary acidification associated with the disturbance of ASS is undoubtedly a major environmental concern for the eastern Australian Sydney rock oyster industry. Table 4 lists oyster producing estuaries in NSW and the estimated areas of high-risk ASS contained in the floodplain. Areas used for oyster production in the Richmond, Macleay, Hastings and Manning Rivers have been impacted by ASS-affected waters and oyster growers have reported ASS related impacts in other estuaries including the Tweed and Shoalhaven Rivers [3]. Other environmental issues facing the industry including diseases, product safety and declining water quality issues compound the problems caused by ASS affected waters.

Impacts caused by ASS induced acidification reach well beyond impacts to aquaculture. Deleterious effects caused by fluctuating $\mathrm{pHs}$ and high concentrations of metals extend to most aquatic organisms inhabiting estuarine systems which is then likely to have ramifications for the broader estuarine ecosystem. The spatial and temporal characteristics of acidified water are important factors to consider when assessing environmental impacts $[6,11,21]$. The spatial extent of acidification can influence the magnitude of mortality events and other impacts $[1,11]$.

\section{Acknowledgements}

The authors thank Dr. Dick Callinan, Bob Smith, Laurie Lardner, Ian and Rose Crisp, Ben Perkins, Graham Dessent, Robert and Nathan Herbert, Stuart Bale, Neil Ellis, Paul Wilson as well as Hastings River and Port Stephens Oyster Growers for their support and interest in this study. Thanks are also due to Dorothy $\mathrm{Yu}$ and Chris Myers for laboratory support and assistance with sample analyses. Drs. Wayne O'Connor and Geoff Allan are 
Table 4. Estuary type and the area of high-risk acid sulfate soils in the catchments of oyster producing estuaries in NSW. Source: Adapted from West et al. [39], NSW Department of Primary Industries [40] and Naylor et al. [7]. "nd" = data not available.

\begin{tabular}{|c|c|c|c|}
\hline Oyster Producing Estuary & Estuary Type & $\begin{array}{l}\text { Total Oyster Production: } \\
\text { 2006/2007 (Dozens) }\end{array}$ & $\begin{array}{l}\text { Area of High Risk ASS } \\
\text { in Catchment (Hectares) }\end{array}$ \\
\hline Tweed River & Drowned River Valley B/C & nd & 9700 \\
\hline Brunswick River & Barrier Lagoon D & - & 3193 \\
\hline Richmond River & Barrier Lagoon D & nd & 34195 \\
\hline Clarence River & Barrier Lagoon D \& C & nd & 53043 \\
\hline Wooli River & Barrier Lagoon D & nd & \multirow{2}{*}{15455} \\
\hline Bellinger River & Barrier Lagoon D & nd & \\
\hline Nambucca River & Barrier Lagoon D & 107,346 & - \\
\hline Macleay River & Barrier Lagoon D & 44,327 & 31644 \\
\hline Hastings River & Barrier Lagoon D & 310,400 & \multirow{2}{*}{21737} \\
\hline Camden Haven & Barrier Lagoon C & 311,353 & \\
\hline Manning River & Barrier Lagoon D & 263,937 & 16884 \\
\hline Wallis Lake & Barrier Lagoon B & $2,320,413$ & \multirow{2}{*}{19069} \\
\hline Port Stephens & Drowned River Valley A \& B & 682,551 & \\
\hline Hunter River & Barrier Lagoon C/D & nd & 26947 \\
\hline Brisbane Waters & Barrier Lagoon A/B & 272,375 & \multirow{2}{*}{8273} \\
\hline Hawkesbury River & Drowned River Valley A \& B & 10,500 & \\
\hline Botany Bay & Coastal Lagoon B/C & nd & \multirow{2}{*}{2979} \\
\hline Georges River & Drowned River Valley B & - & \\
\hline Shoalhaven River & Barrier Lagoon D & 48,675 & \multirow{2}{*}{7584} \\
\hline Crookhaven River & Barrier Lagoon C & 122,634 & \\
\hline Conjola River & Barrier Lagoon A & - & \multirow{2}{*}{4114} \\
\hline Clyde River & Drowned River Valley B/C & 770,337 & \\
\hline Tomaga River & Barrier Lagoon D & - & - \\
\hline Tuross Lake & Barrier Lagoon C & 80,215 & \multirow{2}{*}{1601} \\
\hline Wagonga Inlet & Barrier Lagoon A & 317,399 & \\
\hline Wallaga Lake & Barrier Lagoon A & - & \multirow{4}{*}{948} \\
\hline Bermagui River & Barrier Lagoon C/D & nd & \\
\hline Wapengo Lake & Barrier Lagoon B/C & 69,305 & \\
\hline Nelson Lagoon & Barrier Lagoon C & nd & \\
\hline Merrimbula Lake & Barrier Lagoon A/B & 251,161 & \multirow{3}{*}{570} \\
\hline Pambula River & Barrier Lagoon B/C & 196,894 & \\
\hline Wonboyn River & Barrier Lagoon C & 55,852 & \\
\hline
\end{tabular}

A to $\mathrm{D}$ refer to the degree of maturity or infilling of the estuary. A-little infilling, D-very infilled. 
thanked for valuable editorial comments during the preparation of this manuscript. This study was supported by Fisheries Research and Development Corporation (Project Number 96/285) and Hastings River Oyster Growers.

\section{REFERENCES}

[1] M. C. Dove and J. Sammut, "Impacts of Estuarine Acidification on Survival and Growth of Sydney Rock Oysters Saccostrea glomerata (Gould, 1850)," Journal of Shellfish Research, Vol. 26, No. 2, 2007, pp. 519-527. doi:10.2983/0730-8000(2007)26[519:IOEAOS]2.0.CO;2

[2] W. A. O'Connor and M. C. Dove, "The Changing Face of Oyster Production in New South Wales, Australia," Journal of Shellfish Research, Vol. 28, No. 4, 2009, pp. 803812. doi: $10.2983 / 035.028 .0409$

[3] I. White, "Safeguarding Environmental Conditions for Oyster Cultivation in New South Wales," Report (Number 010801) for the NSW Healthy Rivers Commission, Sydney, 2002.

[4] J. A. Nell and B. Perkins, "Evaluation of the Progeny of Third-Generation Sydney Rock Oyster Saccostrea glomerata (Gould, 1850) Breeding Lines for Resistance to QX Disease Marteilia sydneyi and Winter Mortality Bonamia roughleyi," Aquaculture Research, Vol. 37, No. 7, 2006, pp. 693-700. doi:10.1111/j.1365-2109.2006.01482.x

[5] D. Dent, "Acid Sulphate Soils: A Baseline for Research and Development," International Institute for Land Reclamation and Improvement, Wageningen, 1986.

[6] J. Sammut, I. White and M. D. Melville, "Acidification of an Estuarine Tributary in Eastern Australia Due to Drainage of Acid Sulfate Soils," Marine and Freshwater Research, Vol. 47, No. 5, 1996, pp. 669-684. doi:10.1071/MF9960669

[7] S. D. Naylor, G. A. Chapman, G. Atkinson, C. L. Murphy, M. J. Tulau, T. C. Flewin, H. B. Milford and D. T. Morand, "Guidelines for the Use of Acid Sulfate Soil Risk Maps," NSW Department of Land and Water Conservation, Sydney, 1995.

[8] M. C. Dove and J. Sammut, "Histologic and Feeding Response of Sydney Rock Oysters, Saccostrea glomerata, to Acid Sulfate Soil Outflows," Journal of Shellfish Research, Vol. 26, No. 2, 2007, pp. 509-518. doi:10.2983/0730-8000(2007)26[509:HAFROS]2.0.CO;2

[9] S. P. Wilson and R. V. Hyne, "Toxicity of Acid-Sulfate Soil Leachate and Aluminium to Embryos of the Sydney Rock Oyster," Ecotoxicology and Environmental Safety, Vol. 37, No. 1, 1997, pp. 30-36. doi:10.1006/eesa.1996.1514

[10] L. M. Parker, P. M. Ross and W. A. O'Connor, "Effect of Ocean Acidification and Temperature on the Fertilisation and Embryonic Development of the Sydney Rock Oyster Saccostrea glomerata (Gould 1850)," Global Change Biology, Vol. 15, No. 9, 2009, pp. 2123-2136. doi:10.1111/j.1365-2486.2009.01895.x

[11] J. Sammut, "Associations between Acid Sulfate Soils, Estuarine Acidification, and Gill and Skin Lesions in Es- tuarine and Freshwater Fish," Ph.D. Dissertation, The University of New South Wales, Sydney, 1998.

[12] B. Smith, "Improving Floodgate and Drain Management on the Hastings Floodplain," Unpublished Report, Robert J. Smith and Associates, Alstonville, 1999.

[13] S. Johnston, "The Effects of Acid Sulphate Soils on Water Quality in the Maria River Estuary, NSW," Report prepared for Ocean Watch, NSW Department of Public Works, NSW Department of Land and Water Conservation, Hastings Council, Commercial Fisheries Advisory Council and Kempsey Shire Council, 1995.

[14] A. Wood, "Acid Sulphate Soils in Anna Bay," The University of Newcastle, Newcastle, 1997.

[15] K. Smith, "The Impacts of Drainage on Acid Sulphate Soils at Anna Bay: A Preliminary Investigation," Report prepared for Department of Land and Water Conservation, The University of Newcastle, Newcastle, 1997.

[16] NSW Department of Primary Industries, "The NSW Oyster Industry Sustainable Aquaculture Strategy," NSW Department of Primary Industries, Port Stephens, 2006.

[17] NSW Marine Park Authority, "Port Stephens-Great Lakes Marine Park Zoning Plan User Guide," NSW Marine Park Authority, Nelson Bay, 2007.

[18] C. E. Boyd, "Water Quality in Warmwater Fish Ponds," Auburn University Press, Alabama, 1979.

[19] APHA, "Standard Methods for the Examination of Water and Wastewater," Centennial Edition, American Public Health Association, New York, 2005.

[20] P. Mulvey, "Pollution, Prevention and Management of Sulphidic Clays and Sands," Proceedings of the National Conference on Acid Sulphate Soils, Coolangatta, 24-25 June 1993, pp. 19-25.

[21] J. Sammut, I. White and M. D. Melville, "Field Measurement of Acid Sulfate Soil Affected Waters," Proceedings of the 2nd National Conference of Acid Sulfate Soils, Coffs Harbour, 5-6 September 1996, pp. 114-119.

[22] Manly Hydraulics Laboratory, "Maria River Water Quality Monitoring," Report MHL760, Prepared for Department of Land and Water Conservation, Manly Hydraulics Laboratory, Manly Vale, 1997.

[23] ERM Mitchell McCotter, "Partridge Creek Acid Sulfate Soils Land Management Plan," Report Prepared for the Hastings Council, Port Macquarie, 1997.

[24] ANZECC, "Australian Water Quality Guidelines for Fresh and Marine Waters," Australian and New Zealand Environment and Conservation Council, Canberra, 2000.

[25] M. C. Dove and S. McOrrie, "Field Notes and Personal Observations From an Investigation of Estuarine Acidification in Wallis Creek and Tilligerry Creek, Port Stephens," Unpublished Report, NSW Department of Primary Industries, Taylors Beach, 2006.

[26] J. Knutzen, "Effects of Decreased pH on Marine Organisms," Marine Pollution Bulletin, Vol. 12, No. 1, 1981, pp. 25-29. doi:10.1016/0025-326X(81)90136-3

[27] R. N. Bamber, "The Effects of Acidic Sea Water on Young Carpet-Shell Clams Venerupis decussata (L.) (Mollusca: Veneracea)," Journal of Experimental Marine 
Biology and Ecology, Vol. 108, No. 3, 1987, pp. 241-260. doi:10.1016/0022-0981(87)90088-8

[28] R. N. Bamber, "The Effects of Acidic Seawater on Three Species of Lamellibranch Mollusc," Journal of Experimental Marine Biology and Ecology, Vol. 143, No. 3, 1990, pp. 181-191. doi:10.1016/0022-0981(90)90069-O

[29] V. L. Loosanoff and F. D. Tommers, "Effect of Low pH Upon Rate of Water Pumping of Oysters, Ostrea virginica," Anatomical Records, Vol. 99, No. 4, 1947, pp. 668-669.

[30] Y. Kuwatani and T. Nishii, "Effects of Decreased pH of Culture Water on the Growth of the Japanese Pearl Oyster," Bulletin of Japanese Society of Science and Fisheries, Vol. 35, No. 4, 1969, pp. 342-350. doi:10.2331/suisan.35.342

[31] F. Gazeau, C. Quiblier, J. M. Jansen, J.-P. Gattuso, J. J. Middleburg, C. Heip and H. R. Carlo, "Impact of Elevated $\mathrm{CO}_{2}$ on Shellfish Calcification," Geophysical Research Letters, Vol. 34, No. 7, 2007, Article ID: L07603. doi:10.1029/2006GL028554

[32] A. Beesley, D. M. Lowe, C. K. Pascoe and S. Widdicombe, "Impact of $\mathrm{CO}_{2}$ Induced Seawater Acidification on the Health of Mytilus edulis," Climate Research, Vol 37, No. 2-3, 2009, pp. 215-225. doi:10.3354/cr00765

[33] R. B. Callinan, "Pathogenesis of Red Spot Disease (Epizootic Ulcerative Syndrome) in Estuarine Fish in Eastern Australia and the Philippines," Ph.D. Dissertation, University of Queensland, Brisbane, 1997.
[34] P. S. Galtsoff, "The American Oyster Crassostrea virginica Gmelin," Fishery Bulletin of the Fish and Wildlife Service, Vol. 64, 1964, pp. 219-238.

[35] C. M. Morrison, "Histology and Cell Ultrastructure of the Mantle and Mantle Lobes of the Eastern Oyster, Crassostrea virginica (Gmelin): A Summary Atlas," American Malacological Bulletin, Vol. 10, No. 1, 1993, pp. 1-24.

[36] J. J. Dwyer III and L. E. Burnett, “Acid-Base Status of the Oyster Crassostrea virginica in Response to Air Exposure and to Infections by Perkinsus marinus," Biological Bulletin, Vol. 190, No. 1, 1996, pp. 139-147. doi:10.2307/1542682

[37] M. C. Dove, "Effects of Estuarine Acidification on Survival and Growth of the Sydney Rock Oyster Saccostrea glomerata," Ph.D. Dissertation, The University of New South Wales, Sydney, 2003.

[38] A. J. S. Hawkins, R. F. M. Smith, B. L. Bayne and M. Heral, "Novel Observations Underlying the Fast Growth of Suspension-Feeding Shellfish in Turbid Environments: Mytilus edulis," Marine Ecology Progress Series, Vol. 131, 1996, pp. 179-190. doi:10.3354/meps 131179

[39] R. West, C. A. Thorogood and R. J. Williams, "An Estuarine Inventory for New South Wales, Australia," NSW Department of Agriculture and Fisheries, Fisheries Bulletin, Vol 2, Sydney, 1985.

[40] NSW Department of Primary Industries, "Aquaculture Production Report 2006/2007," NSW Department of Primary Industries, Port Stephens, 2008. 